\title{
RUNX1 Gene
}

National Cancer Institute

\section{Source}

National Cancer Institute. RUNX1 Gene. NCI Thesaurus. Code C18579.

This gene plays a role in transcriptional regulation and cytogenetic aberrations are associated with several leukemias. 